\title{
Genre en plot georiënteerde narratief-kritiese eksegese van Evangeliemateriaal: Inleiding tot narratiewe kritiek
}

\author{
Andries G van Aarde ${ }^{1}$ \\ Emeritus professor: Fakulteit Teologie \\ Universiteit van Pretoria
}

\begin{abstract}
Genre and plot oriented exegesis of Gospel material: Introducing narrative criticism

This contribution to methodology and hermeneutics, consisting of two articles, aim to argue for combining historical criticism and narrative criticism. The first article shows how genre orientation can provide hermeneutical cues for determining an appropriate exegetical model and method. The article aims to apply Gérard Genette's narratology as a narrative-critical model for the exegesis of Gospel material. The article focuses on the role plot analysis fulfills in narrative criticism. This discussion is illustrated with examples from the Gospels of Mark, Luke, Matthew and John. The article concludes with a preface to the second article in which aspects such as point of view and focalization, time and space, and characterization will be discussed, also applied to Gospel material.
\end{abstract}

\section{INLEIDING - 'N VOORWOORD TOT TWEE BYDRAES}

Die postmoderne eksegeet en teoloog, Herman C Waetjen (emeritusprofessor van die Graduate Theological Union in Berkeley en dosent verbonde aan die Presbiteriaanse Kerk se San Anselmo Theological Seminary in Kalifornië, jarelank internasionale adviserende lid van die redaksie van HTS Teologiese Studies en gewaardeeerde vriend van skrywer)

\footnotetext{
${ }^{1}$ Andries $\mathrm{G}$ van Aarde is emeritus professor in die Departement Nuwe-Testamentiese Wetenskap, Fakulteit Teologie, Universiteit van Pretoria. Hierdie artikel word opgevolg met 'n tweede, getitel "Vertellersperspektiefanalise van Nuwe-Testamentiese tekste". Beide artikels is met goedkeuring verwerkings in Afrikaans van 'n Engelse opstel, "Narrative criticism of the New Testament", wat in 'n bundel oor eksegetiese metodologie en hermeneutiek in die reeks Guide to the New Testament, Volume III, onder redaksie van A B du Toit deur Protea Publishing House uitgegee gaan word.
} 


\section{Genre en plot georiënteerde narratief-kritiese eksegese}

maak in sy resente en epogmakende werk oor die Evangelie van Johannes ${ }^{2}$ die volgende opmerking: "The Age of Enlightenment's hermeneutics of historical-critical methodology that engages in a critical construction of the Gospel's original context appears to be a necessary prerequisite for an intelligent and informed reading of the Gospel." Komende van 'n selferkende postmoderne hermeneut - wat bekend is vir sy sosiaal-wetenskaplike, ideologies-kritiese en kerklik-lojale publikasies oor Nuwe-Testamentiese geskrifte - is hierdie waarderende woorde oor die waarde van die historiese kritiek nogal van betekenis. ${ }^{3}$ Dit eggo ook my eie siening - self 'n selferkende postmoderne hermeneut wat dikwels teenoor vriende die opmerking maak dat Herman Waetjen dié Nuwe-Testamentikus is wat, volgens my eie mening, die naaste aan my eie ideologiese perspektief eksegese en teologie beoefen.

Dit kom daarom nie as 'n verrassing nie dat Waetjen die kennisteoretiese en -filosofiese vertrekpunte van sy histories-kritiese interpretasie van die Evangelie van Johannes laat saamsmelt met die narratief-kritiese insigte van R Alan Culpepper, soos uitgewerk in Culpepper se Anatomy of the Fourth Gospel (1983). ${ }^{4}$ In die in memoriam-Festschrift ter ere van wyle Sjef van Tilborg, One text, a thousand methods (2005), maak een van die redakteurs, Patrick Chatelion Counet (2005:17) die volgende opmerking oor my eie bydrae (Van Aarde 2005:161-178) in die Festschrift: "In line with the notions of Van Tilborg, van Aarde shows that narrative exegesis needs not disregard the historical situation within which a particular text communicates." Sodanige "inklusiewe" benadering tot die eksegese van die Nuwe Testament weerspieël inderdaad my diep oortuiging.

Die onderhawige eksegeties-metodologiese bydrae het as bedoeling om in twee opvolgende artikels 'n inleiding tot narratiewe kritiek te bied. In die eerste artikel word aangesluit by die redes waarom 'n postmoderne uitleg van die Nuwe Testament nie by die historiese kritiek, ten spyte van die onontberende bydrae daarvan, kan bly stil staan nie. Die eerste artikel fokus

\footnotetext{
${ }^{2}$ Herman, C Waetjen 2005. The Gospel of the beloved disciple: A work in two editions. New York: T \& T Clark.

${ }^{3}$ Kyk toekomstige publikasie van beplande artikel(s) in HTS oor die historiese kritiek deur A G van Aarde.

${ }^{4}$ In die inleiding tot sy werk oor die Evangelie van Johannes haal Waetjen (2005:xiv) die volgende woorde van Cuplpepper (1983:4) aan: "As one reads the gospel, the voice of the narrator introduces the narrative world of the text, its characters, values, norms, conflicts, and the events which constitute the plot of the story. The narrator conveys the author's perspective to the reader and send signals which establish expectations, distance and intimacy, and powerfully affect the reader's sense of identification and involvement. The narrator's claims and the norms of the story woo, beckon, and challenge the reader to believe that the story, its narrative world, and its central character reveal something profoundly true about the 'real' world in which the reader lives."
} 
veral op die rol wat genre-identifikasie en plot-analise in die eksegese van Evangeliemateriaal speel. Daar word van die teoretiese standpunt uitgegaan dat genre ' $n$ sinkroniese aangeleentheid is wat die eksegeet daartoe lei om ' $n$ narratief-kritiese model en metode van eksegese as betekenisskeppend te beskou. Die narratologie van Gérard Genette (1980) word gekies as model in terme waarvan 'n narratief-kritiese metode ontwerp word. Aandag word gegee aan die rol wat plot-analise in die interpretasie van die vier Evangelies in die Nuwe Testament vervul. Hierdie bespreking word telkens met voorbeelde uit Evangeliemateriaal toegelig. In die tweede artikel word daar ingegaan op ander narratief-kritiese aspekte, soos veral vertellersperspektief - weer eens met voorbeelde uit die Markus-, Lukas-, Matteus- en Johannesevangelie geïllustreer.

\section{GENRE EN EKSEGESE - INLEIDENDE OPMERKINGS}

In die tradisioneel histories-kritiese paradigma het die onderskeid tussen genres nie sondermeer daartoe gelei dat verskillende metodes van uitleg in die eksegese van Nuwe-Testamentiese tekste gevolg is nie. Historiese kritiek is geïnteresseerd in die evolusionêre wording van 'n geskrif (kyk Lategan 1982:58; Vorster 1982:94). Histories-kritici stel nie per se belang in die literêre komposisie van die literêre eindproduk nie. Selfs in gevalle wanneer historieskritiese eksegete wel ondersoek doen na die struktuur en komposisie van 'n dokument, is hulle primêre belangstelling eerder gerig op die proses van die redaksionele verwerking wat daartoe aanleiding gegee het dat 'n "nuwe" geskrif geskep is (vgl Kesich 1972:41; Vorster 1982:107). Die fokus val op die geskiedenis van die dokument. Pertinente vrae sou wees: wie het 'n dokument geskryf en op wie is dit gerig; wanneer en waar is dit geskryf? Die vooronderstelling is dat insig in die historiese proses van die daarstelling van die dokument die eksegeet kan help om antwoorde op hierdie vrae oor oorsake en gevolge te kry. Gesien in die lig van die kennisteoretiese en filosofiese perspektiewe van die histories-kritiese benadering word alle literatuursoorte in die Nuwe Testament, ongeag of dit 'n evangelie, brief, acta ( $d$ w s "handelinge" van een of ander outoritêre figuur soos 'n apostel) of apokalips is, op dieselfde wyse ondersoek.

Hoewel sodanige histories-kritiese ondersoeke belangrike inligting ooor tekste bied, het eksegete egter toenemend begin besef dat die soeke na die betekenis van 'n teks meer behels as net 'n histories-kritiese ondersoek na die verhouding tussen oorsaak en gevolg of om tussen vorm en inhoud te onderskei. ${ }^{5}$ William Doty (1972:430) verduidelik dit soos volg: "That genre

\footnotetext{
${ }^{5}$ Kennisteoretiese aspekte soos die verbande tussen "oorsaak en gevolg" en "vorm en inhoud" word in die beplande artikel(s) oor die historiese kritiek deur die skrywer bespreek.
} 
must stand at least partly to indicate something beyond form, I take to be selfevident. Meaning, a common way to designate this additional factor, is genrebound ... since generic expression must rank among the most important signal-systems used by the author." Genre as sodanig het egter nie die metode van histories-kritiese eksegese gedikteer nie. Dit is te verstane want genre is 'n sinkroniese verskynsel, ${ }^{6}$ terwyl die historiese kritiek 'n diakroniese benadering is.'

Wat die term genre betref, verwys dit na die generiese kenmerke van 'n bepaalde literêre soort, dit wel sê na die teks se vorm. Dit is omdat se formele kenmerke van ander tipes verskil dat die eksegeet in staat gestel word om 'n bepaalde literatuursoort te kan onderskei. Poësie is duidelik van prosa te onderskei en in die Nuwe Testament toon die evangelievorm ook duidelik ander kenmerke as 'n brief. In die evangelies is gelykenisse weer te onderskei van byvoorbeeld strydgesprekke en wondervertellings (kyk Tatum [1982] 1999:46-47). Tradisioneel is die Nuwe Testament breedweg onderverdeel in die literatuursoorte evangelie, acta (die Handelinge van die Apostels), briewe en apokalips (die Openbaring van Johannes). Vanweë genres se eiesoortige kenmerke, sal eksegete 'n brief anders benader as wat hulle sou doen in die geval van 'n evangelie (kyk Vorster 1977:18-20; vgl Anderegg 1977). Die evangelies, acta en apokalips is voorbeelde van narratiewe tekste, terwyl briewe as voorbeeld van 'n redevoering dien.

\footnotetext{
${ }^{6}$ Geoff Webb (2006:38-42), na aanleiding van die literatuurteoretikus Clive Thompson (1984) se navorsing oor Mikhail Bakhtin, meen egter dat die "studie van genres" in wese ("essentially") 'n diakroniese ondersoek is. Webb (2006:38) haal Thomson aan: "[The study of genres is essentially] a diachronic study of how forms enter into combinations with other forms." Elke voorbeeld van 'n "generiese tipe" is inderdaad, soos Webb beweer, 'n "new textevent" (Webb 2006:39) en dit is so dat 'n nuwe "text-event" op diakroniese wyse opereer, omdat nuwe gebruikers 'n bestaande generiese tipe op grond van "remembering" (Webb 2006:39) - dit wil sê op diakroniese wyse - in 'n "nuwe" teks transformeer. Die gebruik van 'n bepaalde genre deur ' $n$ taalgebruiker maak egter nie van genre as sodanig ' $n$ diakroniese verskynsel nie. Bakhtin (1999:106) sê self: " A genre is always the same and yet not the same, always old and new simultaneously. Genre is reborn and renewed at every stage in the development of literature and in every individual work of given genre. This constitutes the life of the genre .... A genre lives in the present, but always remembers its past, its beginning. Genre is a representative of creative memory in the process of literary development." In die histories-kritiese paradigma (kyk beplande toekomstige artikel) het Formgeschichte aan die literêre ontwikkeling (d w s die evolusionêre geskiedenis van die "generiese vorm" van 'n teks) aandag gegee. In narratiewe kritiek word die fokus egter geplaas op die poëtiese kenmerke van die "generiese vorm" - en anders as die historiese kritiek is so 'n literatuurteoretiese benadering 'n sinkroniese onderneming.

${ }^{7}$ Die literatuurteoretikus, Janet Levarie Smarr (1993:4), verwys soos volg na hierdie ontwikkeling: "Recent approaches within both history and literary criticism make possible a new movement toward each other. For while the New Historical critics have turned from New Criticism and structuralism toward a revived interest in history, and have drawn on historians such as Foucault to provide fresh projects and directions for their thinking, simultaneously historical theorists have turned toward literature and literary theory to open new perspectives on their own field."
} 


\section{NARRATIEWE EN ARGUMENTATIEWE DISKOERSE}

Die rol wat struktuuranalise in filosofie en hermeneutiek begin speel het, het daartoe gelei dat eksegete aandag gee het aan literatuurteorieë wat nie historisiteit as sodanig in gedagte het nie (kyk Mieke Bal 1991:14-23). 'n Prominente aspek van moderne strukturele literatuurteorie is dat literatuursoort 'n sterk invloed uitoefen op die keuse van die tipe eksegetiese metode waarmee 'n bepaalde geskrif ondersoek word. Wat die Nuwe Testament betref, kan ons in 'n sekere opsig breedweg twee strukturele tipe tekssoorte onderskei (wat dus afwyk van die tradisionele vierdeling), te wete narratiewe diskoerse en redevoerings (Anderegg 1977). Die evangelies, acta en apokalips is voorbeelde van narratiewe tekste, terwyl briewe as voorbeeld van ' $n$ redevoering dien (kyk Vorster 1977:18-20).

Redevoerings kan wel as mikrotekste in verhalende literatuur voorkom en vertelmateriaal kan ook in 'n redevoering voorkom en dan wel as makroteks. Die literatuursoort van die makroteks sal egter die eksegetiese metode dikteer en die mikroteks sal dus as onderdeel van die geheelteks hanteer word. So byvoorbeeld, wat verhalende literatuur betref, behoort die narratiewe funksie van redevoerende diskoerse as mikrotekste (bv in die Evangelie van Matteus en Johannes) of van 'n brief as mikroteks (bv Hand 15:23-29) nie uit die oog verloor te word nie. Net so sal verhalende elemente in redevoerende materiaal (bv die narratio-gedeeltes in briewe) retories binne die raamwerk van die groter argument benader word (kyk Burton L Mack 1990:41-43, 56).

Dit is ook moontlik dat 'n eksegeet 'n redevoering kan laat baseer op 'n onderliggende verhaal waarop die bepaalde argument fokus. So byvoorbeeld, het ons in een van die redevoerende dokumente in die Nuwe Testament - die brief van Paulus aan Filemon - die storie van 'n slaaf wat van sy eienaar weggeloop het. Norman R Petersen (1985) het 'n "narratiewe" eksegese van hierdie brief van Paulus gedoen. Die briefskrywer konfronteer die slawemeester met die argument dat beide hy (die meester) en die briefskrywer, asook die slaaf aan dieselfde geestelike familie behoort. Daarom behoort die meester die slaaf as 'n soort "verlore seun" terug te ontvang.

\section{NARRATIEWE POËTIEK}

\subsection{Die bou van 'n vertelling}

Volgens James L Resseguie (2005:18 nota 4), was die term "narrative criticism" vir die eerste keer deur David Rhoads in an article getitel "Narrative 


\title{
Genre en plot georiënteerde narratief-kritiese eksegese
}

criticism and the Gospel of Mark" (Rhoads 1982:411-434) gebruik. ${ }^{8}$

Narratiewe kritiek bemoei sigself met die poëtiek van 'n evangelie as 'n narratiewe diskoers. Die herkoms van die woord "poëtiek" is afgelei van die Griekse woord poeîn, wat beteken "om te maak". ${ }^{9}$ Dit verwys na die wyse waarop taal in 'n diskoers georganiseer is (Uspensky 1973), dit wil sê die wyse waarop 'n teks gemaak is as óf narratief óf argument. Resseguie (2005:18) stel dit soos volg:

\begin{abstract}
Narrative criticism focuses on how biblical literature works as literature. The "what" of a text (its content) and the "how" of a text (its rhetoric and structure) are analyzed as a complete tapestry, an organic whole. Narrative critics are primarily concerned with the literariness of biblical narratives - that is, the qualities that make them literature.
\end{abstract}

Narratologie is 'n literatuurteoretiese benadering waarvolgens narratiewe literatuur ontleed word. ${ }^{10}$ 'n Evangelie kan as verhalende literatuur geanaliseer word, omdat die mees elementêre verskynsels wat die essensie van 'n vertelling uitmaak in die evangelievorm aanwesig is. Dit is naamlik 'n verteller, 'n verhaal en 'n bepaalde leser. Die essensie van die vertelkuns lê in die interrelasies van verteller en verhaal en van verteller en leser/hoorder (vgl Chatman 1978:116-126; Moore 1989:41-55; Powell 1990:51-67; Kingsbury 1997:3).

Wanneer lewensgebeure (mense se sosiale konteks) as storie gekommunikeer word, volg die verhaal 'n bepaalde narratiewe struktuur. ${ }^{11} \mathrm{~N} T$ Wright (1992:38) stel dit soos volg: "Human life, then, can be seen as

\footnotetext{
${ }^{8}$ Reprinted in David Rhoads, Reading Mark: Engaging the Gospel (Minneapolis: Fortress, 2004, chapter 1). Ander baanbrekerswerk op die gebied van narratiewe analises van evangeliemateriaal is onder andere Petersen (1978), Vorster (1980), Van Aarde (1982b, 1983) en Resseguie (1982).

${ }^{9}$ Hierdie Griekse woord word in die klassieke antieke tyd veral deur Aristoteles gebruik in sy Peri poietekes (Butcher 1951; kyk vertaling en uitleg in Afrikaans deur De Kock \& Cilliers 1991).

${ }^{10}$ Daar bestaan ook ander "narratief-analitiese" benaderings waarvolgens Evangeliemateriaal ontleed kan word. Van hierdie benaderings is die so genoemde "aktante-model" van A J Greimas (as onderdeel van die "Franse strukturalisme") waarskynlik die bekendste (kyk o a Patte 1976; Patte \& Patte 1978; Pelser 1983; asook die kritiek deur Thiselton 1978).

${ }^{11}$ Die volgende uitspraak van MacIntyre ([1981] 1985:211) is sprekend van hierdie insig (kyk Wright 1992:38 e v): "Just as history is not a sequence of actions, but the concept of an action is that of a moment in an actual or possible history abstracted for some purpose from that history, so the characters in a history are not a collection of persons, but the concept of a person is that of a character abstracted from a history." Vir publikasies oor hierdie wye onderwerp, kyk onder andere Frei (1974); Alter (1981); Ricoeur (1984, 1985, 1988); Funk (1988); Hauerwas \& Jones (1989); Milbank (1990); Wright (1992).
} 
grounded in and constituted by the implicit or explicit stories which humans tell themselves and one another ... Stories are a basic constituent of human life; they are in fact, one key element within the total construction of a worldview." Narratiewe kommunikasie bevat ten minste vier basiese perspektiewe: die skrywer wat die storie saamstel, die verteller wat die verhaal vertel, die leser wat dit ontvang en die karakters wat deelneem aan die verhaal. Die analitiese proses in die eksegese van 'n narratiewe diskoers behoort dus daarop gerig te wees om die volgende interrelasies te te ontknoop:

1. narratiewe diskoers < - > bedoelde historiese leser

2. bedoelde historiese leser $<->$ implisiete skrywer

3. implisiete skrywer < - > implisiete leser/luisteraar

4. implisiete skrywer $<->$ verteller

5. verteller $<->$ aanhoorder (narratee)

6. verteller $<->$ vertelde karakters

7. vertelde karakters in wedersydse betrekkinge wat binne 'n bepaalde struktuur van tyd en ruimte afspeel.

Die eerste interrelasie het betrekking op die kommunikasie tussen die werklike skrywer en die bedoelde leser/luisteraar. Dit verwys na diegene wie se sosiale konteks in die narratiewe diskoers verhaal word en wat die eksegeet, ten einde die teks na behore te interpreteer as kommunikasiegebeure, so ver as moontlik op "sosiaal-wetenskaplike" ${ }^{\text {12 }}$ wyse behoort te konstrueer.

Eksegete is uiteraard ook 'n werklike lesers, maar die aard van hulle bemoeienis en invloed met betrekking tot die ontvangs van 'n narratiewe diskoers, is ten nouste gekoppel aan hulle konstruksie van die sosiohistoriese konteks van die werklike skrywer en die bedoelde historiese lesers/luisteraars. Hierdie konstruksie is onder andere afhanklik van kennis van tekste, van sosiale en kulturele norme en van die sosio-kulturele konteks (kyk Uspensky 1973; Lotman 1975; Danow 1987). Hoe meer die konstruksie in terme van 'n daargestelde sosiaal-wetenskaplike model (kyk Elliott 1993) geskied, des te beter.

Voorbeelde 3-7 in die diagram oor interrelasies in 'n narratiewe diskoers hierbo behels intratekstuele narratiewe ordening. Verskeie semeiostruktureel georiënteerde studies het op hierdie strukturele ordening

\footnotetext{
${ }^{12}$ Sosiaal-wetenskaplike kritiek speel 'n belangrike rol in eksegetiese metodologie (kyk Van Aarde 2006a).
} 


\section{Genre en plot georiënteerde narratief-kritiese eksegese}

gefokus. ${ }^{13}$ Volgens die narratiewe model van Gérard Genette (1980:26-27) bestaan 'n narratief uit drie dele: narratiewe diskoers, storie en die vertellersituasie. ' $n$ Geïmpliseerde skrywer laat 'n verteller vertel (die vertellersituasie, ook genoem die narratiewe proses) dít wat die verteller self (die "verteller-fokaliseerder") of 'n karakter (die "karakter-fokaliseerder") in die verhaal sien (die storie) wat ander karakters in 'n gegewe struktuur van tyd en ruimte (die narratiewe diskoers) doen. Die verteller se posisie kan as die "vertellende proses" (narrating process) beskryf word. Die "narratiewe diskoers" (in Frans bekend as recit) is vir die eksegeet direk toeganklik, terwyl die "storie" (histoire) vanuit die narratiewe diskoers geabstraheer moet word. Die interaksie tussen die skrywersituasie en die narratiewe diskoers word gewoonlik in terme van - wat tegnies bekend staan as - "fokalisering" beskryf. Hierdie drie vlakke (narratiewe diskoers, storie en fokalisering) vorm die basiese struktuur van 'n narrative diskoers.

' $n$ Teks kan nie as ' $n$ naratief getipeer word as die gebeure wat daarin vervat word, nie 'n liniêre, kronologiese reeks, wat 'n verhaal vorm, konstitueer nie. Dit is slegs wanneer die gebeure, wat op 'n gegewe tyd en plek in die lewens van mense plaasvind, geselekteer word om in 'n oorsaakgevolg verband in ' $n$ reeks van insidente (episodes) saam te val en sodoende 'n plot te ontwikkel, dat die storie 'n narratiewe diskoers word.

'n Narratiewe diskoers is dus ' $n$ georganiseerde vertelling en dit is so 'n gestruktureerde teks wat die eksegeet moet ontleed. Dit is egter nie die liniêrkronologiese storie as sodanig wat direk tot die beskikking van die eksegeet is nie. Die "storie" moet nog eers vanuit die gestruktureerde narratiewe diskoers geabstraheer word. Sodanige abstraksie is hermeneuties van belang. Die rede hiervoor is dat die eksegeet die boodskap (ook genoem die "ideologiese perspektief") van 'n vertelling konstrueer deur die tegnieke - wat gebruik is om 'n storie ("histoire") in 'n narratiewe diskoers ("recit") te giet - te identifiseer en te verklaar. Dit wil sê, dit is nodig dat "storie" nie as dieselfde as die "narratiewe diskoers" gesien word nie - storie word uit die narratiewe diskoers geabstraheer.

Die analise van die narratiewe diskoers is primêr gerig op beskrywing van dít wat karakters in hulle resiproke relasies doen. Sodanige analise is ' $n$ voorvereiste vir die abstrahering van die storie. Dit wat die karakters in hulle onderskeie relasies doen, kan op vyf vlakke gevisualiseer word, te wete die emotiewe ("psigologiese") vlak, die fraseringsvlak ("fraseologiese"), die temporele, ruimtelike en ideologiese vlakke (kyk Lanser 1981:184-225; vgl

\footnotetext{
${ }^{13}$ Die so genoemde "Franse strukturalisme" (kyk ook voetnota 10) is een van die bekendse voorbeelde in die literatuurteorie en is veral in die tagtigterjare deur die eksegeet en teoloog van Vanderbilt University in die VSA, Daniel Patte, op Nuwe-Tetatentiese tekste toegepas (kyk Patte 1981a, 1981b, 1983, 1987, 1990).
} 
Rhoads 1982:421; Van Aarde 1983:61-62; Tolmie 1999:29-30; Resseguie 2005:169-172). Hierdie vyf vlakke is onlosmaaklik gekoppel aan die posisie(s) wat die verteller in die narratief (hierbo genoem: "fokalisasie"). ${ }^{14}$ Die hoeke van waaruit die verteller die storie vertel, bepaal die manier waarop en ideologiese perspektief(we) van waaruit die handelinge van die karakters deur die verteller aangebied word. Naas die storie en narratiewe diskoers, is die vertellersituasie (narratiewe proses) dus die derde deel van 'n teks wat generies as narratief getipeer word.

Sover het dit duidelik geword dat 'n narratief gedefinieer kan word as 'n diskoers waarin taal georganiseer is in terme van karakters wat in 'n bepaalde struktuur van tyd en ruimte beweeg. Hierdie "struktuur" bestaan daaruit dat dié beweging van karakters in episodes ontvou. Die episodes ontwikkel in kronologies-sekwensiële (d w s opeenvolgende) handelingslyne (aksies).

Tot die mate wat die handelinge van karakters in kousale verband met mekaar staan, is daar in elke sekwensie interaksies. Dit is hierdie kousaliteit van aksies wat die plot van 'n narratiewe diskoers vorm. Hierdie struktuur van interaksie van karakters (verhoudinge wat in terme van tyd en ruimte uitgedruk word) kan óf baie simpleks óf baie kompleks van aard wees. In die diagram oor interrelasies in 'n narratiewe diskoers hierbo vorm relasies 2 tot 6 die boustene van 'n vertelling se plot. Plot is 'n intratekstuele aangeleentheid en word nie deur buite-tekstuele aspekte soos die interrelasie tussen skrywer en verteller en dié tussen reële leser en implisiete lesers/hoorders beïnvloed nie.

\subsection{Plot-analise}

Die studie van plot behels veel meer as 'n blote fokus op die liniêre verloop van die gebeure of die maak van 'n optelsom van die onderskeie gebeure en episodes om by die betekenis van die vertelling uit te kom. Deur episodes in 'n vertelling bloot langs mekaar te plaas sodat dit 'n liniêre patroon vertoon, is nog nie dieselfde as om die struktuur van die vertelling se plot te identifiseer nie. Die somtotaal van die episodes maak nie die plot van die vertelling uit nie. Dit is eers wanneer die eksegeet kan aantoon hoedat sekere elemente in 'n vertelling in verhouding met ander in dieselfde vertelling staan en hoe die outeur die onderskeie episodes georganiseer het ten einde 'n bepaalde kommunikatiewe effek te bereik, dat hierdie "optelsom" van episodes as die plot van die vertelling beskryf kan word.

\footnotetext{
${ }^{14} \mathrm{Kyk}$ later, veral wat betref die interaksie tussen storie, narratiewe diskoers en vertellerssituasie - wat in die Genette-benadering in terme van die konsep "fokalisering" beskryf word.
} 
'n Elementêre, goed gestruktureerde plot bestaan uit 'n liniêre sekwensie wat 'n aanvang, middel en einde het. ${ }^{15}$ Ter wille van die kommunikatiewe effek staan elkeen van hierdie elemente in 'n bepaalde verhouding tot die ander. Die begin van die plot lei die aksie in en skep 'n verwagting by die implisiete leser/hoorder. Die handeling wat vroeër geïnisieer is, word in die middeldeel ontwikkel en 'n ontknoping (dénouement), wat in die einde voltrek word, word reeds veronderstel.

\subsubsection{Die plot van die Evangelie van Lukas as voorbeeld}

\subsubsection{Op Lukas se makrovlak}

Op makrovlak is die Evangelie van Lukas 'n goeie voorbeeld van 'n gestruktureerde plot wat uit 'n begin, middel en slot bestaan. Die boodskap (d w s die ideologiese perspektief van die verteller) van hierdie Evangelie word gekenmerk deur 'n universele skopus. Jesus van Nasaret word nie alleen as die Messias (Christós) van Israel uitgebeeld nie, maar word as Heer (Kuríos) en Verlosser (Sōtēr) van die hele wêreld uitgebeeld (kyk Van Zyl \& Van Aarde 1997:185-208).

In die sosio-historiese konteks van die bedoelde historiese lesers van Lukas word Jesus as "verlosser" in opposisie met die Romeinse keiser as "verlosser" gesien (kyk o a Patterson 1998:61-64). Deur Jesus as "Christus" ('n verlossersbegrip vir gelowiges met Israelse oriëntasie) en "Heer" ('n verlossersbegrip vir gelowiges met Grieks-Romeinse oriëntasie) te erken, kom daarop neer om God met lofprysing en danksegging te eer en te erken dat die koninkryk van God in en deur Jesus "na jou toe" (in Luk 17:21 in Grieks: entós humōn; in Engels: "onto you") kom.

Die begrip "koninkryk" het 'n politieke konnotasie en volgens Lukas is God se koninkryk 'n alternatief op die koninkryk van die Romeinse keiser. Die bereidheid om met so 'n alternatief saam te leef, vereis volgens Lukas dat jy onvoorwaardelik Jesus op sy reis van Nasaret na Jerusalem sal volg (kyk Luk 9:57-62). In Lukas se plot is Jerusalem die plek waar Jesus se finale "kroning" volgens God se plan en wil sal plaasvind. Sy koninklike verlosserskap en heerskappy manifesteer in weerwil van - of juis danksy - sy dood en opstanding.

Die lede van die huis van Israel (soos deur bv die Fariseërs verteenwoordig) en Jesus se potensiële volgelinge (soos deur bv die dissipels verteenwoordig) word regdeur Lukas se plot uitgedaag om "om te keer" (in die Bybel dikwels die tegniese term wat gebruik word om na bekering te verwys)

\footnotetext{
${ }^{15}$ Dit is ' $n$ insig wat reeds deur Aristoteles in sy Peri poietekes gemaak is (kyk weer voetnota 9).
} 
en om Jesus op sy weg vanaf Nasaret na Jerusalem te volg. Dit is 'n reis wat Lukas $(9: 51,53)$ op ietwat "onlogiese" wyse beskryf as synde "op pad tussen Samaria en Galilea". ${ }^{16}$ Samaria is die plek wat Judeërs vermy. Lukas wil klaarblyklik "ruimtelik" op 'n simboliese wyse aandui dat hindernisse (tot die mate wat die roete deur "onaanvaarbare" streek soos Samaria lei) onderweg voorkom (kyk Thomas \& Van Aarde 1998:736-785). Hierdie struikelblok bemoeilik die keuse van die dissipels om bereid te wees om Jesus onvoorwaardelik te volg en sodoende die wyse waarop God koning is (as alternatief op die wyse waarop die Romeinse keiser heers) te aanvaar.

Spanning in die plot van Lukas se verhaal word juis daardeur geskep dat ongewone kategorieë mense, uitgeworpenes soos byvoorbeeld herders (Luk 2:8-20), ${ }^{17}$ vreemdelinge (o a Luk 17:18) en misdadigers (Luk 23:32-43), en nie die leiers van Israel of die dissipels nie, die bekeerlinge word wat Jesus volg en God prys.

Die begin en einde van Lukas se evangelie, asook 'n episode in die middel, kan as "vreugdevolle" tempeltonele in Jerusalem beskryf word tonele waarin God geprys en gedank word. In die eerste van hierdie tonele word Jesus se geboorte en dié van sy voorganger, Johannes die Doper (Luk $1: 8,14)$ aangekondig. Die middelste toneel vertel die verhaal van die triomfantlike intog (Luk 19:38). In die finale episode het "al die dissipels" na "Jerusalem toe teruggegaan" en "God in die tempel geprys" (Luk 24:53).

Die begingedeelte van Lukas se vertelling is die verhaal van Josef en Maria wat van Nasaret na Bethlehem onderweg was. Hierdie verhaal word opgevolg met die een oor die herders en engele wat verenig was in lofprysing van God deur erkenning te bring aan die nuutgebore koning Jesus as "Christus en Heer" wat met sy roepings-lerings-en-helende bediening in Galilea begin (Luk 1:1-9:50). Die middelgedeelte bestaan uit die reis na Jerusalem (Luk 9:51-19:40). Direk na afloop van die genesingstoneel waarin “"n vreemdeling van Samaria" (Samarítēs ... allogenēs - Luk 17:17, 18) God prys, het Jesus Jerusalem ingegaan waar "'n hele skare dissipels" se stemme die lied van herders en engele herhaal: "Loof die Koning, Hy wat in die Naam van die Here kom! Vrede in die hemel en eer aan God in die hoogste hemel" (Luk 19:38). Die vertellings oor die kruisigings-, opstandings- en

\footnotetext{
${ }^{16}$ Geografies maak so 'n beskrywing nie sin nie, omdat Samaria en Galilea nie "langs mekaar" geleë is sodat 'n pelgrim in die Bybelse tyd vanuit Galilea na Jersualem, asof dit streke is wat "langs mekaar" geleë is, sal reis nie. Die Markusevangelie (vgl 9:32 met 10:46) beskryf Jesus se reis vanaf Galilea na Jerusalem as 'n pad wat by Jerigo verbygegaan het.

${ }^{17}$ Kyk onder andere Stiller (2005:188 nota 5): "Interestingly, although the biblical shepherd was a cherished image of care for God's people, first-century shepherds were generally despised by the average Jew, due to their reputation for lawlessness and dishonesty (cf. b. Sanhedrin 25b) (Blomberg [1990:],180).
} 


\section{Genre en plot georiënteerde narratief-kritiese eksegese}

herverskyningstonele (Luk 19:41-24:53) vorm die slotgedeelte. Na afloop van die storie van die twee misdadigers wat weerskante van Jesus gekruisig is en waarvan die een versoek het dat Jesus aan hom moes dink wanneer Hy in sy koninkryk kom (Luk 23:39-43), het die dissipels ná Jesus se hemelvaart weer na Jerusalem teruggekeer. Daar het hulle God die hele tyd geprys (Luk 24:5053).

\subsubsection{Op Lukas se mikrovlak}

Die bou van 'n plot uit 'n begin-, middel- en slotgedeelte is in ' $n$ hele aantal kleiner vertellings in die Evangelie van Lukas aanduibaar. Die kombinasie van die twee so genoemde "quest-stories" in Lukas 17:20-21 en 17:22-37 kan as voorbeeld dien. Die eerste vertelling handel oor 'n gesprek tussen Jesus en die Fariseërs (Luk 17:20-21) en die tweede oor 'n gesprek tussen Jesus en die dissipels (Luk 17:22-37). Aan die begin van die plot wil die Fariseërs weet "wanneer" (in Grieks: póte) die koninkryk van God gaan kom (Luk 17:20 e v). Aan die einde wil die dissipels weet "waar" (d w s "op watter plek") (in Grieks: poû) die koninkryk gaan kom (Luk 17:37). Die middelste gedeelte van hierdie mikrovertelling bestaan uit die vergelyking wat Jesus tussen twee tipes voornemende volgelinge tref. Aan die een kant is daar diegene wat meen dat hulle hulleself kan red deur hulle alledaagse lewensverpligtinge met toewyding uit te voer - dit wil sê 'n tipe godsdienstigheid wat vandag "burgerlike godsdiens" genoem word. ${ }^{18}$

Volgens Lukas kan so 'n "verburgerlikte godsdienstige" gesindheid egter nie as navolging van Jesus beskryf word nie, want dit getuig nie van 'n onvoorwaardelike prioriteit aan die Jesus-saak nie. Diesulkes se kulturele konvensies het voorkeur bo die navolging van Jesus. En hoewel hulle kan dink dat so 'n lewenshouding nie ongodsdienstig is nie, ${ }^{19}$ bly hulle toewyding futiel. Hulle het nie insig daarin dat die "koninkryk wat in hulle midde is", vra dat hulle kulturele konvensies aan die evangelie ondergeskik gestel moet word nie. Dan is daar aan die ander kant diegene wat bereid is om hulle lewens prys te gee. Deur Jesus onvoorwaardelik te volg, wys hulle dat die navolging van die boodskap ' $n$ veel groter prioriteit as die alledaagse lewe is (Luk 17:22-35).

Jesus se metaforiese antwoord op die "wanneer"-vraag (wat aan die begin van hierdie mikovertelling gestel word - Luk 17:20-21), is dat God se

\footnotetext{
${ }^{18}$ In hedendaagse godsdienssosiologie is dit veral Peter Berger (1961:39-57) wat maan teen "burgerlike godsdiens" wat hy as "slegte geloof" (bad faith) beskryf.

${ }^{19} \mathrm{Vgl} \mathrm{ook}$ Paulus in Romeine 10:3 wat so 'n gesindheid "eiegeregtigheid" noem (kyk veral die werk van Lucien Legrand 2000, The Bible on culture: Belonging or dissenting?, veral bls 111112).
} 
tipe "koninklike teenwoordigheid" in en deur Jesus ${ }^{20}$ so duidelik soos weerlig in 'n donderstorm is. Ook die antwoord op die "waar"-vraag (wat aan die einde gestel word - Luk 17:37) is in die vorm van 'n matafoor. Die verwysing na arende (Luk 17:37) ${ }^{21}$ wat op hulle prooi toesak (as aanduiding van die Romeinse owerhede wat Jesus doodgemaak het - vgl Carter 2002), is Lukas se uitbeelding van die waar, die hoe en die wanneer 'n mens jou eie lewe op paradoksale wyse red ten spyte van die feit dat jy dit verloor net soos Jesus syne aan die kruis verloor het. Om Jesus na te volg vra dat jy ook soos Jesus jou kruis sal opneem.

\subsection{Die dénouement van 'n plot}

Plot en karakterisering is interafhanklik omdat die gebeure of handelinge in 'n vertelling deur die resiproke relasies van karakters bepaal word. Die interaksies tussen karakters dra by tot ontwikkeling by sommige karakters wat die implisiete lesers/hoorders mag verras. Die verrassingselement skep spanning en hierdie spanning kan óf suksesvol in die dénouement ontknoop óf die plot kan abortief eindig, in welke geval die spanning voortduur.

In 'n sekere sin lei 'n suksesvolle einde van 'n verhaal nie na 'n algehele oplossing van al die spanning by die implisiete lesers/hoorders nie. In die meeste goed georganiseerde vertellings bly die einde oop (vgl Norman Petersen 1980). Die implisiete lesers/hoorders word as gevolg van die spanning wat in die verhaal op grond van die karakters se interaksies geskep is, by die plot ingetrek en raak by die interaksies betrokke. Hierdie betrokkenheid vorm die intrige (stratagem) van die verhaal. Die plot, oftewel die intrige, wat reeds in die verhaal geskep is en in die verloop van die verhaal ontvou, word ook na afloop van die fisiese vertelling van die verhaal voortgesit. Stratagem is dus die gevolg van 'n plot met 'n oop-einde, omdat

\footnotetext{
${ }^{20}$ In Lukas 13:18-19, in Jesus se gelykenis oor die mosterdsaad, word die koninkryk van God vergelyk met God se versorging van mense wat as die "onreinste van die onreines" (die "illegitimate, tainted, unclean", uitgebeeld met mosterdsaad - kyk Scott 1989:374-387) beskou kan word. Luise Schotroff (2006:120) verstaan die bedoeling van hierdie vergelyking as "praxis of love of enemies". Die volgende opmerking van Schottrof (2006:123) kan ter harte geneem word: "Quite frequently I have found in the exegetical history of the twentieth century, and still today, a variation on this interpretation that compares the insignificance of the mustrad seed with the insignificance of the Jesus movement or the church of a particular time. To this insignificant beginning is promised the great and glorious future of the kingdom of God. Thus the kingdom of God becomes the future of the church, an ominous misunderstanding. Even when Jesus' presence and the little group around him are interpreted allegorically as the insignificant musterd seed, this little group appears as the kernel of the church of whatever present moment - even if only implicitly. I must be clearly said that is spoken of here is not some future church, but God and God's future, nothing else. This future is present strenght for human hope, for all who learn to see creation with new eyes."

${ }^{21}$ Lukas 17:36 verskyn nie in die meer outentieke oorspronklike weergawe van die storie nie.
} 
die plotlintrige in die lewensverhaal van die lesers/hoorders gekontinueer word - selfs wanneer die woorde en sinne op papier tot ' $n$ einde gekom het.

\subsubsection{Die Evangelies as voorbeelde van vertellings met oop-eindes}

Die kanonieke evangelies is goeie voorbeelde van vertellings met sodanige oop-eindes.

\subsubsection{Die Evangelie van Lukas}

Lukas se fisiese vertelling van Jesus se reis vanaf Galilea eindig in Jerusalem. In Lukas se verhaal verteenwoordig Jerusalem 'n klimaks. Jerusalem vorm 'n hoogtepunt omdat die opgestane Christus dáár aan die apostels verskyn en dáár na die hemel opgevaar het. Na Jesus se hemelvaart het die dissipels na Jerusalem teruggekeer (Luk 24:52-53). Lukas self het ' $n$ oop-einde en die verhaal vervolg in Handelinge, wat die vervolgverhaal van die Evangelie van Lukas is. In Handelinge reis die apostels van Jerusalem na Rome.

\subsubsection{Die Evangelie van Markus}

Markus se plot het 'n soortgelyke oop-einde wat die storie van die kerk ná Jesus se opstanding verder vertel. Markus se fisiese "finale" episode word in hoofstuk 16:1-8 berig. Reeds in hoofstuk 14:28 het Jesus volgens Markus 'n hereniging tussen Hom en sy dissipels in Galilea na s dood en opstanding geantisipeer. Hierdie hereniging word egter self nooit in die fisiese narratief vertel nie - juis hierdie spanningskeppende antisipasie veroorsaak dat die vertelling 'n oop-einde het.

Op sy unieke manier het Matteus se verhaal ook 'n oop-einde. In die konklusie in Matteus 28:16-20 vind ' $n$ hereniging tussen Jesus en sy dissipels wel in Galilea plaas, maar die vraag of die dissipels hulle opdrag ten uitvoer gaan bring, bly onbeantwoord. In Markus en Matteus neem Galilea (en nie Jerusalem, soos wat in Lukas die geval is nie) die belangrike plek van Jesus se opstanding in. In Markus vorm die nuus van Jesus se opstanding en die aankondiging van die opgestane Jesus aan Maria Magdalena dat hy aan sy dissipels in Galilea gaan verskyn, ' $n$ dramatiese fisiese slot vir die evangelie, maar in werklikheid is dit bloot ' $n$ oënskynlike einde. Anders as wat die geval in Handelinge is, word die storie van die kerk op ' $n$ eie besondere manier in beide Markus en in Matteus vertel deurdat dit eerder geïmpliseer word as wat dit fisies verhaal word.

Nadat Jesus in Jerusalem oor die verwerping deur sy teenstanders getriomfeer het en sy volgelinge op sy kruisiging en opstanding gereageer het, word die plot in Markus 16:1-8 (en in Matt 28:16-20) in die vertel van die 
lewensverhaal van die lesers - wat nou die rol van die dissipels moet verder voer - voortgesit. Die slot van die Evangelie van Markus bied 'n uitdaging aan die lesers: Sal hulle byvoorbeeld handel soos die mans en vroue wat Jesus vanaf Galilea gevolg het? Markus vertel hoedat mans (wat veronderstel is om dapper te wees) ironies genoeg van die kruis weggevlug het omdat hulle, anders as Jesus, nie bereid was om hulle kruis te dra nie. Die vroue weer (wat veronderstel is om te weet wat dit is om geboorte aan nuwe lewe te gee) het ironies genoeg van die oop graf weggevlug. Hiermee toon hulle dat ook hulle nie in staat was om die getuies van die begin van die nuwe lewe (wat deur Jesus se opstanding moontlik gemaak is) te wees nie (vgl Malbon 1983:2948).

\subsubsection{Die Evangelie van Matteus}

In Matteus bied die storie van die "groot opdrag" in Matteus 28:16-20 'n uitdaging aan die lesers (kyk Van Aarde 2006b:103-122) wat op grond van die oop-einde van Matteus se plot die intrige van Matteus se vertelling kontinueer. Die "groot sendingopdrag" was die laaste keer dat ons van die dissipels in die Matteusevangelie verneem. Wat het met hulle vóór hierdie grand finale gebeur? Hulle het van die kruis weggehardloop, terwyl 'n paar dapper vroue die nuus vir hulle gebring het dat Jesus tog die finale oorwinning behaal het. In hierdie laaste episode kry jy hulle weer by Jesus op die berg in Galilea (kyk Donaldson 1985). Die ou wet van Moses wat op Sinaï gegee is, word aan hulle nuut geproklameer deur die "Tweede Moses" (Allison 1993) wat die oorwinning oor die dood behaal het. 'n Mens kan verwag dat al hulle vroeëre kleingeloof nou uit die weggeruim is, maar dit gebeur nie. Dit is maar die herhaling van die ou storie: van die dissipels wat vroeër saam met Jesus op die see wou loop en dit nie kon doen nie; wat saam met Jesus in Getsemane wou wees, maar nie kon saam waak nie; wat saam met Jesus na Golgota wou gaan, maar dit nie kon regkry nie; wat nou, hoewel die oorwinnende Jesus aan hulle verskyn, steeds nie hulle kleingeloof kan oorwin nie. Dit is sulke struikelende mense wat die "groot sendingopdrag" ontvang. En wat in die lesers se ore na afloop van die fisiese verhaal eggo - en dus 'n oop-einde skep - is die ambivalensie van om te glo én tegelykertyd te twyfel (Matt 14:31; 28:17) (Ellis 1967-1968:576; vgl Van Aarde 1982a:21-34).

\subsubsection{Die Evangelie van Johannes}

Wat Johannes betref, sorg die spanningsbelaaide interaksie tussen Petrus en die "geliefde dissipel" in Johannes 21 vir 'n dramatiese oop-einde aan die einde van hierdie Evangelie. Ook Johannes se plot ontvou in die verloop van die vertelling. Aan die einde van die geskrewe Evangelie word die verhaal in 


\section{Genre en plot georiënteerde narratief-kritiese eksegese}

die lewe van die gemeenskap vir wie Johannes sy verhaal geskryf het, voortgesit (kyk Van Aarde 1985:45-62). ${ }^{22}$ Op grond van die opgestane Jesus se enigmatiese woorde aan Petrus oor die beweerde onsterflikheid van die "geliefde dissipel" (Joh 21:20-23), blyk dit dat die "geliefde dissipel" (afgesien daarvan dat hy óf 'n historiese óf 'n fiktiewe figuur is) tydens die skrywe van hoofstuk 21 reeds dood was. Johannes 21 vorm as addendum 'n oop-einde wat tot die fisiese slot van die Johannesevangelie toegevoeg is. In Hierdie addendum verwys die skrywer van hoofstuk 21 na hoofstuk 13:23 waar Johannes vir die eerste keer in sy plot verig oor die opposisie tussen Petrus en die "geliefde dissipel" (wat ook in o a hoofstukke 1-20 aanwesig is). Die spanning wat hierdie opposisie skep, word in die oop-einde, selfs na die fisiese slot van die teks, gekontinueer.

\subsection{Plot-analise en identifisering van spanning}

Kernagtig gesien, is dit die bedoeling van narratiewe kritiek om 'n narratiewe diskoers se plot te beskryf. Daarom is dit vir die eksegeet nodig om duidelikheid te verkry oor wat die plot in die verhaal is. Dit is egter belangrik om in gedagte te hou dat intrige ("stratagem") en plot, hoewel onlosmaaklik aan mekaar gekoppel, verskillende konsepte is. Stratagem het te make met die spanning in die plot. Dit volg op die suksesvolle of abortiewe dénouement (ontknoping) van 'n vertelling se plot wat weer op grond van karakters se onderlinge resiproke relasies ontstaan.

Stratagem is die resultaat van die verhouding wat in 'n vertelling tussen die verrassingselemente en die elemente van spanning en afwagting bestaan. Soos wat die verteller die plot ontwikkel en as 'n gevolg daarvan dat verwagtings by die implisiete leser/hoorder gewek is, suggereer die verteller 'n assosiasie of 'n disassosiasie tussen die lesers/hoorders en die karakters wat

\footnotetext{
${ }^{22}$ Hoewel hoofstuk 21, tekskrities gesien, saam met die res van die Johannesevangelie oorgelewer is, word algemeen aanvaar dat dit op grond van saaklike en letterkundige oorwegings nie die werk van een en dieselfde skrywer is nie (kyk Waetjen 2005:8-15). Tog is duidelik dat daar wel 'n soort literêre verwantskap tussen hoofstukke 1-20 en hoofstuk 21 bestaan. Waetjen (2005:3-60) argumenteer dat hoofstukke 1-20 in Aleksandrië ontstaan het en die addendum in hoofstuk 21 in Efese. Verskillende eksegete het verskillende opinies kyk onder andere Bultmann ([1956] 1967); Lindars (1971:27-42; 1972:46-54); Fortna (1970, 1988); Martyn (1986:99-121). Ten spyte van die verskillende argumente, dui die werk van hierdie eksegete daarop dat die skrywer van hoofstuk 21 afhanklik was van die skrywer van hoofstukke 1-20. Dit kan veral gesien word in die naasmekaar, opposisionele plasing van die "geliefde dssipel" en Petrus (vgl veral Joh 21:7 - "Die dissipel vir wie Jesus baie lief was, sê toe vir Petrus: 'Dit is die Here!'," asook Johannes 21:20-23 - "Toe Petrus omdraai, sien hy die dissipel volg vir wie Jesus baie lief was, wat ook by die maaltyd na Jesus se kant toe oorgeleun en gevra het: 'Here, wie is u verraaier?' [Joh 13:23]. Toe Petrus hom dan sien, vra Petrus vir Jesus: 'Here, en wat van hom?' Jesus antwoord hom: 'As Ek wil hê dat hy in die lewe moet bly totdat Ek weer kom, is dit nie jou saak nie. Volg jy My!' Die gerug het toe onder die broers versprei dat daardie dissipel nie sal sterwe nie, maar: 'As Ek wil hê dat hy in die lewe moet bly totdat Ek weer kom, is dit nie jou saak nie'."
} 
in die vertelling in interaksie met mekaar verkeer. Assosiasie veronderstel simpatie en disassosiasie antipatie. Onsekerheid by die leser oor wat met veral daardie karakters gaan gebeuer met wie die leser/hoorder assosieer of disassosieer, dra by tot 'n spanningsvolle afwagting - en so word die plot van die verhaal gebou.

'n Bepaalde effek word by die leser/hoorder gewek wanneer die verteller sekere inligting tot beskikking van die leser/hoorder stel, terwyl hierdie inligting van die karakters weerhou word. So byvoorbeeld vertel die verteller van die Evangelie van Johannes reeds in hoofstuk 13:2 dat die duiwel die plan om Jesus te verraai in Judas Iskariot se hart geplaas het selfs nog voordat vertel word dat Judas self so 'n plan gehad het of inderdaad tot die beplanning van die verraad oorgegaan het.

Wanneer karakters met onverwagse verrassings vorendag kom, dra dit tot verhoogde spanning by. Dit kom daarop neer dat die eksegeet intrige identifiseer wanneer daar in die geval van die liniêr-sekwensiële verloop van die plot 'n kousaliteit tussen die gebeure of episodes van gebeure aangetoon kan word.

\section{5. 'N EPILOOG AS VOORWOORD}

Vanuit die perspektief van die genre-onderskeid tussen narratiewe en argumentatiewe diskoerse is daar in hierdie artikel inleidend aandag gegee aan die vraag wat "narratiewe eksegese" behels. Dit is gedoen aan die hand van 'n verduideliking van begrippe soos narratiewe poëtiek, narratiewe kommunikasie, plot en intrige. Die artikel het begin met 'n verwysing na wat as 'n "inklusiewe" benadering tot eksegetiese metodologie en hermeneutiek bestempel is. Net soos aan die begin van die artikel kan daar ten slotte, as antisipasie op 'n volgende artikel waarin spesifiek aan aspekte soos point of view en fokalisasie aandag gegee sal word, met 'n opmerking van Herman Waetjen (2005:xvii, xix), in aansluiting by die narratief-kritiese werk van $R$ Alan Culpepper (1983), geëindig word:

The post-modern orientation of Culpepper's Anatomy prioritizes meaning in place of analysis and consequently accentuates the original objective of the Gospel; that is, to engender an experience by rhetorically drawing the implied readers' into a narrative world that necessitates existential experience. In view of the predispositions laid down in the text for the literary work to exercise its affects, in view of the gaps and blanks that the implied readers are expected o fill, to what extent will contemporary readers be able to produce the meaning encoded in the Gospel? Without any fusion of horizons that historical criticism can generate between the text and the contemporary readers and without any literary competence 


\section{Genre en plot georiënteerde narratief-kritiese eksegese}

in reading, a purely subjective interpretation of the text will result in a limited and tradition-bound projection arising out of the act of reading. The resulting meaning is nothing more that a recycled repetition of the reader's prejudices projected into the text. In contrast, the meaning that is potentially constituted by the textual structures of the implied reader can only be actualized by "informed readers" who possess an historical sense of the Gospel's original context and an attendant literary competence ... Some of the knowledge that tradition provides may open the text and initiate the process of entering into the textual structures of the implied reader. But a reader fusion of horizons, combining historical-critical information of the text's context and literary skill in reading, is essential if the dialectical experience of both the immediacy and the distanciation that the text potentially offers is to be actualized.

\section{Literatuurverwysings}

Allison, D C jr 1993. The new Moses: A Matthean typology. Minneapolis, MN: Fortress.

Alter R 1981. The art of biblical narrative. New York: Basic books.

Anderegg, J 1977. Fiktion und Kommunikation: Ein Beitrag zur Theorie der Prosa. Göttingen: Vandenhoeck \& Ruprecht.

Bakhtin, M M 1999. Problems of Dostoevsky's poetics, ed by C Emerson. Minneapolis, MN: University of Minnesota Press.

Bal, M 1991. In story-telling: Essays in narratology. Sonoma, CA: Polebridge.

Berger, P 1961. The noise of solemn assemblies: Christian commitment and the religious establishment in America. Garden City, NY: Doubleday.

Blomberg, C I 1990. Interpreting the parables. Downers Grove, IL: InterVarsity.

Bultmann, R [1956] 1967. Das Evangelium des Johannes. (Ergänzungsheft 1967). Vandenhoeck \& Ruprecht.

Butcher, S H 1951. Aristotle's theory of poetry and fine art: With a critical text and translation of the Poetics. $4^{\text {th }}$ edition. New York: Dover.

Carter, W 2002. Are there Imperial texts in the class? Intertextual eagles and Matthean eschatology as lights out time for imperial Rome (Mt 24:27-31). Unpublished paper, Matthew Seminar of the Studiorum Novi Testamenti Societas, $57^{\text {th }}$ Annual Meeting, University of Durham, August 6-10, 2002.

Chatelion Counet, P 2005. Introduction, in Chatelion Counet, P \& Berges, U 2005, One text, a thousand methods: Studies in memory of Sjef van Tilborg, 1-18. Boston, MA: Brill Academic Publishers.

Chatman, S 1978. Story and discourse: Narrative structure in fiction and film. Ithaca, NY: Cornell University Press.

Culpepper, R A 1983. Anatomy of the Fourth Gospel: A study in literary design. Philadelphia, PA: Fortress.

Danow, D K 1987. Lotman and Uspensky. A perfusion of models. Semiotica 64, 343357.

De Kock, E L \& Cilliers, L 1991. Aristoteles poetika: Vertaling en uitleg van betekenis. Johannesburg: Perskor. 
Donaldson, T L 1985. Jesus on the mountain: A study in Matthean theology. Sheffield: JSOT. (JSNTS 8.)

Doty, W G 1972. The concept of genre in literary analysis, in McGouchy, L C (ed), SBL Proceedings, Vol 2: Book of Seminar Papers, 413-448. Philadelphia, PA: Fortress.

Elliott, J H 1993. What is social-scientific criticism? Minneapolis, MN: Fortress.

Ellis, I P 1967-1968. But some doubted. NTS 14, 574-580.

Fortna, R T 1970. The Gospel of Signs: The chief narrative source underlying the Fourth Gospel. Cambridge: Cambridge University Press.

Fortna, R T 1988. The Fourth Gospel and its predecessor: From narrative source to present Gospel. Philadelphia, PA: Fortress.

Frei, H W 1974. The eclipse of biblical narrative: $A$ study in eighteen and nineteenth century hermeneutics. New Haven, CT: Yale University Press.

Funk, R W 1988. The poetics of biblical narrative. Sonoma, CA: Polebridge.

Genette, G 1980. Narrative discourse: An essay in method, tr by J E Lewin. Ithaca, NY: Cornell University Press.

Hauerwas, S \& Jones, L G J (eds) 1989. Why narrative? Readings in narrative theology. Grand Rapids, MI: Eerdmans.

Kesich, $V$ 1972. The gospel image of Christ: The church and modern criticism. New York: St Vladimir's Seminar Papers.

Kingsbury, J D 1997. The plot of Matthew's story, in Kingsbury, J D (ed), Gospel interpretation: Narrative-critical and social-scientific approaches, 16-26. Philadelphia, PA: Trinity Press International.

Lategan, B C 1982. Inleiding tot de uitlegging van het Nieuwe Testament, in Klijn, A F $\mathrm{J}$ (red), Inleiding tot de studie van het Nieuwe testament, 47-70. Kampen: Kok.

Legrand, L 2000. The Bible on culture: Belonging or dissenting? Maryknoll, NY: Orbis Books.

Lindars, B 1971. Behind the Fourth Gospel. London: SPCK.

Lindars, B 1972. The Gospel of John. London: Marshall, Morgan \& Scott.

Lotman, J M 1975. Point of view in a text. New Literary History 6, 339-352.

Macintyre, A C [1981] 1985. After virtue: A study in moral theory, 2nd edition. Notre Dame, IN: Notre Dame University Press.

Mack, B L 1990. Rhetoric and the New Testament. Minneapolis, MN:Fortress. (NT Series. Guides to Biblical Scholarship.)

Malbon, E S 1983. Fallible followers: Women and men in the Gospel of Mark. Semeia 28, 29-48.

Martyn, J L 1986. Source criticism and Religionsgeschichte in the Fourth Gospel, in Ashton, J (ed), The interpretation of John, 99-121. Philadelphia, PA: Fortress.

Midbank, J 1990. Theology and social theory: Beyond secular reason. Oxford: Blackwell. (Signposts in Theology.)

Moore, S D 1989. Literary criticism and the gospels: The theoretical challenge. New Haven, MA: Yale University Press.

Patterson, S J 1998. The God of Jesus: The historical Jesus \& the search for meaning. Harrisburg, PA: Trinity Press International.

Patte, D 1976. What is structural exegesis? Philadelphia, PA: Fortress. 


\section{Genre en plot georiënteerde narratief-kritiese eksegese}

Patte, D 1981a. Elements of a semiotic of didactic discourse: Analysis of 1

Thessalonians. Documents de Travail Series, of the Centro Internazionale di Semiotica e di Linguistica. Urbino: University of Urbino Press.

Patte, D 1981b. "Elements of a semiotic of didactic discourse": Method for a structural exegesis of didactic discourses. Semeia 26, 85-129.

Patte, D 1983. Method for a structural exegesis of didactic discourses: Analysis of 1 Thessalonians, in Narrative and discourse in structural exegesis: John 6 and

1 Thessalonians. Semeia 26, 85-129.

Patte, D 1987. The Gospel according to Matthew: A structural commentary on Matthew's faith. Philadelphia, PA: Fortress.

Patte, D 1990. The religious dimensions of biblical texts: Greimas's structural semiotics and biblical exegesis. Atlanta, GA: Scholars Press. (Semeia Studies Series.)

Patte, D \& Patte A 1978. Structural exegesis: From theory to practice. Philadelphia, PA: Fortress.

Pelser, G M M 1983. Die aktante-model van A J Greimas, in Van Aarde, A G (red), Interpretasiemodelle in Evangelienavorsing, 35-57. Universiteit van Pretoria, Departement Nuwe-Testamentiese Wetenskap (Afd A).

Petersen, N R 1978. "Point of view" in Mark's narrative. Semeia 12, 97-121.

Petersen, N R 1980. When is the end not the end? Litery reflections on the ending of Mark's narrative. Interp 34, 151-166.

Petersen, N R 1985. Rediscovering Paul: Philemon and the sociology of Paul's narrative world. Philadelphia, PA: Fortress.

Powell, M A 1990. What is narrative criticism? Minneapolis, MN: Fortress.

Resseguie, J L 1982. Point of view in the central section of Luke (9:51-19:44). Journal of the Evangelical Theological Society 25, 41-47.

Resseguie, J L 2005. Narrative criticism of the New Testament. Grand Rapids, MI: Baker Academic.

Rhoads, D 1982. Narrative criticism and the Gospel of Mark. JAAR 50, 411-434. [repr in Rhoads, D 2004. Reading Mark: Engaging the Gospel, chapter 1. Minneapolis, MN: Fortress.]

Rhoads, D \& Dewey, J \& and Mitchie, D 1999. Mark as story: An introduction to the narrative of a gospel. $2^{\text {nd }}$ ed. Minneapolis, MN: Fortress.

Ricoeur, P 1984. Time and narrative, vol I. Chicago: Chigago University Press.

Ricoeur, P 1985. Time and narrative, vol 2. Chicago: Chigago University Press.

Ricoeur, $\mathrm{P}$ 1988. Time and narrative, vol 3. Chicago: Chigago University Press.

Ricoeur, $\mathrm{P}$ 1995. Figuring the sacred: Religion, narrative and imagination, tr by $\mathrm{D}$ Pellauer and ed by M I Wallace. Minneapolis, MN: Fortress.

Scott, B B 1989. Hear then the parable: A commentary on the parables of Jesus. Minneapolis, MN: Fortress.

Scottroff, L 2006. The parables of Jesus, tr by L M Maloney. Minneapolis, MN: Fortress.

Smarr, J L 1993. Introduction, in Smarr, J L (ed), Historical critcism and the challenge of theory, 1-24. Urbana, IL: University of Illinois Press.

Stiller, B C 2005. Preaching parables to postmoderns. Mineapolis, MN: Fortress. (Fortress Resources for Preaching.)

Tatum, W B [1982] 1999. In quest of Jesus. Revised and enlarged edition. Nashville, TN: Abingdon. 
Tolmie, D F 1999. Narratology and biblical narratives: A practical guide. San Francisco, CA: International Scholars Publications.

Thiselton, A 1978. Structuralism and biblical studies: Method or ideology? Expository Times 89, 329-335.

Thompson, C 1984. Bakhtin's theory of genre. Studies in Twentieth Century Literature 9(1), 29-40.

Thomas, A \& Van Aarde, A G 1998. Samaria as belangeruimte in Lukas-Handelinge. HTS 54(3\&4), 736-788.

Uspensky, B 1973. A poetics of composition: The structure of the artistic text and typology of a compositional form, tr by $\vee$ Zavarin and S Wittig. Berkeley, CA: Berkeley University Press.

Van Aarde, A G 1982a. Matthew's portrayal of the disciples and the structure of Matthew 13:53-17:27. Neot 16, 21-34.

Van Aarde, A G 1982b. God-met-ons: Dié teologiese perspektief van die Matteusevangelie. DD-proefskrif, Universiteit van Pretoria.

Van Aarde, A G 1983. Die vertellersperspektief-analise: 'n Literatuurteoretiese benadering in die eksegese van die Evangelies, in Van Aarde, A G (red), Interpretasiemodelle in Evangelienavorsing, 58-83. Universiteit van Pretoria, Departement Nuwe-Testamentiese Wetenskap (Afd A).

Van Aarde, A G 1985. Die outeurskapsvraag van die Johannesevangelie met die oog op interpretasie of resepsie. Skrif \& Kerk 6, 45-62.

Van Aarde, A G 2005. Resolving communication disturbances in Luke 12:35-48 through narratology, in Chatelion Counet, P \& Berges, U 2005, One text, a thousand methods: Studies in memory of Sjef van Tilborg, 161-178. Boston, MA: Brill Academic Publishers.

Van Aarde, A G 2006a. Inleiding tot die sosiaal-wetenskaplike kritiek van NuweTestamentiese tekste. Beplande artikel vir HTS.

Van Aarde, A G 2006b. Hoe om in te kom en hoe om binne te bly - die "groot sendingopdrag" aan die kerk vandag volgens Matteus 28:16-20. HTS 62(1), 103-122.

Van Zyl, S \& Van Aarde, A G 1997. Die Lukaanse Jesusbeeld: In dialoog met Wilhelm Bousset se "Kyrios Christos". HTS 53(1\&2), 185-208.

Vorster, W S 1977. 'n Ou boek in 'n nuwe wêreld: Gedagtes rondom die interpretasie van die Nuwe Testament. Inaugural Lecture. Pretoria: University of South Africa. (Miscellanea 10.)

Vorster, W S 1980. Die evangelie volgens Markus: Inleiding en teologie, in Du Toit, A B (red), Handleiding by die Nuwe testament, IV: Die Sinoptiese Evangelies en Handelinge, 109-155. Pretoria: NG Kerkboekhandel.

Vorster, W S 1982. De structuuranalyse, in Klijn, A F J (red), Inleiding tot de studie van het Nieuwe testament, 127-152. Kampen: Kok.

Waetjen, H C 2005. The Gospel of the beloved disciple: A work in two editions. New York: T \& T Clark.

Webb, G 2006. Bakhtin's poetics and the Gospels: Genre-memory and its possible application to the Gospel of Mark. The Council of Societies for the Study of Religion Bulletin 35(2), 38-42.

Wright, N T 1992. Christian origins and the question of God, vol 1: The New Testament and the people of God. Minneapolis, MN: Fortress. 